\title{
Deficiencies in pastoral care with prisoners in Cameroon
}

\begin{abstract}
Authors:
Abraham K. Akih ${ }^{1}$

Yolanda Dreyer ${ }^{1}$

Affiliations:

${ }^{1}$ Department of Practical Theology, University of

Pretoria, South Africa

Correspondence to:

Yolanda Dreyer

Email:

yolanda.dreyer@up.ac.za

Postal Address:

Faculty of Theology, University of Pretoria,

Lynnwood Road, Hatfield

0083, Pretoria, South Africa

Dates:

Received: 21 Dec. 2011

Accepted: 08 June 2012

Published: 15 Aug. 2012

How to cite this article:

Akih, A.K. \& Dreyer, Y., 2012,

'Deficiencies in pastoral care with prisoners in cameroon', HTS Teologiese Studies/

Theological Studies 68(1),

Art. \#1210, 7 pages. http://

dx.doi.org/10.4102/hts.

v68i1.1210
\end{abstract}

C 2012. The Authors. Licensee: AOSIS OpenJournals. This work is licensed under the Creative Commons Attribution License.
Cameroon celebrated fifty years of independence from colonial rule on 20 May 2010. Major problems facing the nation are economic, social and political crises and the appalling condition of its prisons. This article focuses on pastoral care with prisoners in Cameroon. Most churches in Cameroon have no pastoral care programme for prisoners. The churches in general are not yet committed to this kind of work. The article argues that changes and reform of the penitential system will be difficult if not impossible without collaboration with other institutions and resources, which include the different faith communities and faith based organisations. The focus should be on the care and well-being of those within its walls if successful rehabilitation is to take place. Spiritual care will contribute to the general well-being of prisoners. The article gives a broad overview of the situation of prisons and prisoners in Cameroon and presents a pastoral care approach that could contribute to the overall improvement of the lives of people in Cameroon prisons.

\section{The situation}

Studies on the social, political and economic situation and state institutions in Cameroon are hampered by strict censorship laws. Research results on issues relating to the economy, good governance, corruption and the plight of the suffering masses in Cameroon are not readily available. Those who undertake such studies risk arrest and imprisonment. Existing literature provides only fragmentary information. Mukong (1990:1-2), an ex-political prisoner, laments the fact that talented scholars in Cameroon are oppressed by censorship. He calls this an impediment to intellectual achievement.

Mukong and others who fought for the independence of Cameroon were constantly harassed, detained and tortured. Boh and Ntemfac (1991:67-71), journalists of the Cameroon Radio and Television (CRTV), describe the prison BMM Kondengui as 'the home of horror and terror' after having seen first-hand to what torment and torture prisoners in detention there were subjected. Some inmates could only rarely leave their cells in the course of three years of detention. More than half the population of BMM Kondengui were prisoners who had committed no crimes and were arrested for no identifiable reason. Wakai (2000:11-20), a retired justice of the Supreme Court of Cameroon and 172 others were arrested for having initiated an opposition political party, the Social Democratic Front (SDF). According to Wakai, democracy was killed in Cameroon on 23 October 1992 when the Supreme Court Justice Dipanda Mouelle failed to give the true results of the presidential elections. The reason he gave was that his hands were tied. An allpowerful executive in effect makes all the decisions and rules the nation. The executive, and not the judiciary, as is the case in the democratic political systems of the world, reviews all judicial decisions. Wakai (2000:55) calls it 'a broken state of law in Cameroon.' Griffith (1993:124) points out the dangers of such a situation and describes it as follows: 'Whenever the state is regarded as the final arbiter of right and truth people are delivered up to be crucified.' Mbembe (2001: $160,186)$, a senior researcher in self-exile in South Africa, describes the leadership in Cameroon as 'autocrats and traditional warriors who, armed with a machete, spear and shield, are ready to cut off the heads not only of their enemies but their most recalcitrant subjects.' Citizens of the country become victims of social injustice and violence is widespread. Njawe (2006:1), publisher of Le Messager newspaper, experienced harassments, beatings and imprisonment by state authorities throughout his journalistic career. He used journalism as a tool to oppose abuse and injustice. Atabong (2007:102, 173), a Roman Catholic cleric and chaplain to the New Bell prison, Douala, asserts that:

prisons in Cameroon are treated as dumping ground, waste basket, garbage dump of those society does not want to see. The prison environment is both a dumping ground for the destitute and a crash course in crime for delinquents. (Atabong 2007:102)

Prisons in Cameroon become the place where the rejects and outcasts of society are kept in appalling conditions. 
Pastoral engagement is mostly absent from most Cameroon prisons. Churches and clergy are yet to venture into the area of pastoral care with prisoners. With regard to prison reform and pastoral care much should still be done. Camp et al. (2006:529) point out that existing studies only date back to round about 1992, before which date nothing much was done about the relationship between religion and adult prisoner rehabilitation. Most prisons in the United States of America, for instance, have a chaplain or team of chaplains who care for inmates and assist them in practicing and expressing their faith (cf. O'Connor \& Duncan 2008:84). This is still only a dream for most prisons in Cameroon.

Duncombe (1992:209) points out that the prison is as much a spiritual problem as it is a social or legal problem.' Even before their incarceration many prisoners have been exposed to an environment where family members and friends exhibit dysfunctional social patterns and anti-social behaviour. Prison chaplains and volunteers, through their ministry of presence, could have a positive impact on the lives of inmates. In order for prisoners to have the opportunity to grow and develop on a personal level and thereby reduce the probability of repeating past patterns of criminal behaviour, it is essential that they are shown different and meaningful ways of relating to the world around them (Hall 2004: 173-174). Atabong (2007:1) argues that prisons form part of the larger psychosocial, economic and spiritual problems that face the Cameroonian nation. Especially at risk are traumatised prisoners who come from dysfunctional homes. They cannot image an alternative, constructive way of living their lives. The physical, psychological and emotional well-being of inmates, facilities that would keep them busy in constructive ways, and religious interventions are possible solutions to the situation of the inmates of prisons in Cameroon.

The objective of this article is to propose an effective pastoral care practice that could play a role in building up the people in prisons. Faith communities tend to view prisons from a distance rather than become involved. However, pastoral care by faith communities could play a life-changing role in the lives of people incarcerated in the prisons in Cameroon.

The objective of the article is to explore ways in which pastoral care by faith communities and pastoral caregivers could contribute to improving a situation that diminishes the humanity of the people who are being kept prisoner. From a theological perspective, the image of God in such people is violated when they are stripped of their dignity as human beings.

Mukong (1990:113), who himself was imprisoned because of his political views and activities, reports that he and his friends did not see faith communities actively involved with prisoners at all. Especially those who were in prison for no reason needed the intervention of believers. Faith communities failed to condemn injustice and corruption and silently looked on as many people were dying in prison. $\mathrm{He}$ expresses his frustration with church leaders and their lack of vision as follows:
Again I ask which religious group has ever considered it an order from above to attend to the prisoners in the BMM and those in the detention centers? Yet we all know that these are the ones who suffer most and furthermore we also know that they have never been condemned by any court of law. And our Lord Jesus Christ shall welcome us to his Father's kingdom for having visited him in prison. (Mukong 1990:113)

The contention of this article is that pastoral care can make a difference to the lives of people in the prisons of Cameroon and could also provide much needed support to those who work to improve prison conditions, such as penitentiary staff, human rights groups, civil societies and non-governmental organisations.

\section{Reform and rehabilitation Prison reform and social reform}

Judicial authorities in Cameroon face much criticism, such as, for instance, that the judiciary is corrupt, ineffective and subject to political influence and that justice is delayed or even denied many prisoners before the trial stage is reached (cf. Wakai 2000:55). This delays the process of prisoners' gaining access to justice and contributes to overcrowding in most prisons across the country.

Imprisonment traumatises not only the inmates but also their families and close relations. Support systems, networks and a positive vision to educate, transform and orientate inmates towards a better life and future are lacking. Rejected by society, prisoners become unwanted individuals whose social and psychological well-being is destroyed by the time they spend in prison (Oppler 1998:36). Matthews and Francis (1996:18) see it as the task of the prison service to provide security, humanity and help. Punishment is not the business of the prisons but of the courts (see Selke 1993:xiii-xiv).

Prison reform has to go hand in hand with social reform. If the prison does not transform and rehabilitate those within its walls and if inmates leave prison worse off than when they went in, the essence of the prison institution can be called into question. Similarly, if material and personnel resources are invested in the prison industry but nothing is achieved, this constitutes wastage of resources. Then imprisonment has failed to correct criminal behaviour and the penitentiary system is not working. According to Selke (1993:138-140 cf. Murphy \& Dison 1990:171; Matthews \& Francis 1996:12; Ward \& Maruna 2008:177) society will continue to live with the disgrace and failures of prisons until a new reality is in place.

\section{Privatisation}

According to James et al. $(1997: 1,6)$ one option for reforming prison systems could be privatisation. Privatisation is fiercely debated in the United States of America, United Kingdom, Australia and South Africa. Those in favour of privatisation, such as Brakel (1988:240), Hutto (1990:11), Logan (1990:167), Harding (1992:7), Hatry, Brownstein and Levinson (1993:199), and James et al. $(1997: 1,6)$ argue that 
this will improve conditions for prisoners, reduce costs for the state and facilitate innovation. Privatisation will bring about competition and new management techniques with the possibility of better quality for less money and more efficiency because of less bureaucratic 'red tape' and a higher motivation to control costs. Proponents of privatisation are optimistic that it will bring visible change to the challenges faced by penitentiary institutions. According to Stern (1998:337), 'prisons can be an expensive way of making bad people worse.'

Those against privatisation, such as Ryan and Ward (1989:17-20, 32-33), Chan (1994:44), McDonald (1994:31), Schichor (1995:11-43), Oppler (1998:58-61) and Ungar (2003:919) point out that accountability for the treatment of prisoners cannot be ensured and that it is the state's absolute and legitimate responsibility to punish those who break the law. Low staffing levels, poor service delivery conditions and poor quality recruits are bound to be the result of a profit driven 'business' approach. The state should live up to its responsibilities in reforming prisons and not delegate this responsibility to corporations or agencies that maximise profits by minimising expenditure (Oppler 1998:58-61; cf. Ungar 2003:919). An example of such a private institution is the Corrections Corporation of America (CCA) which manages several prisons in the United States of America, United Kingdom, South Africa and Australia (see James et al. 1997:6; Oppler 1998:58-61; Ungar 2003:919).

\section{Prison chaplaincy}

A different kind of change can be brought about in prisons through spiritual intervention, pastoral care services and chaplaincy activities by churches and other faith based organisations. According to O'Neill (2009):

the purpose of prison ministry is to give inmates a plan for salvation, a way to move on with their lives, to form inside of them a kind of discipline, to pray, read scriptures and relate to people properly. (pp. 74-75)

According to Skotnicki (2000:2) in times past, prisons have always had a certain religious quality attached to them.

Duncombe (1992:194-209) argues that prison chaplaincy should address the problems of shaky religious foundations, a lack of vision and realistic plans for a person's life, as well as the shame and self-deception that is prevalent amongst inmates. The aim would be to improve the provision of pastoral care in prisons in order to provide a stronger prophetic voice on issues with regard to prisoners, and to provide a meaningful humane service in the prisons. Nothing is as important as nurturing a vision for people who find themselves on the margins of society. According to Allard and Allard (2010:332), prison chaplaincy has the aim to focus on pastoral care and counselling, a ministry of preaching, listening and accompanying prisoners on their journey towards transformation and healing.

Correctional services in Canada, the United States, the United Kingdom, Australia, Denmark, Norway, South
Africa, Sweden and Uganda have made great strides in improving pastoral care networks for inmates as well as with regard to rehabilitation and transformation (see Gendreau \& Andrews 1990:173-184; Duncombe 1992:194-209; Skotnicki 2000:2; Hall 2003:108-137; O'Neill 2009:74-75; Allard \& Allard 2010:330-332). The prison system should change its way of working to one that would provide opportunities for inmates to choose a lifestyle that would depart from the familiar cycle of crime and detention (Duncombe 1992:209). However, prison institutions are faced with challenges that most governments cannot address effectively. Rehabilitation programmes are often scarce, sometimes non-existent, which leaves inmates without support during their time of incarceration. This is where the churches could step in and pastoral care could make a difference in the lives of inmates.

However, pastoral care is mostly seen as voluntary work. Sometimes prison chaplains and coordinators are appointed, but without any real support from either the church or the government. Others respond to the need in prisons and visit prisoners even without having been officially appointed by their churches. Pastoral care by faith communities to prisoners in Cameroon is not yet a vital ministry and the government also does not yet see its potential value. Governmentsponsored chaplains are hard to find in Cameroon prisons (Atabong 2007:25).

\section{Rehabilitation vs punishment}

According to Decree 92/052 of 27 March 1992 the vision for the Cameroon penitentiary system and administration is threefold: protection of society, punishment for wrongdoing and rehabilitation of offenders through work, training and counselling. However, lack of adequate material, personnel and financial resources hinders the realisation of the above goals (see Skotnicki 2000:2). In general prisoners do not have enough land to produce their own food. They are malnourished, live in congested cells and do not receive life skills training whilst incarcerated. Hunger makes them aggressive. They fight and steal. Prison structures are outdated and overcrowded with facilities that are an affront to human dignity.

The prevalent attitude with regard to the Cameroon prison system is that prisoners should pay severely for crimes committed against society and the state. Prisons are for punishment not rehabilitation and therefore the focus is not on education and imparting life skills. Prisons in Cameroon are in a bad state of repair. Overcrowding, poor living conditions, inadequate medical care, slow access to justice and an arbitrary system of prison discipline are some of the problems. Prison conditions are deliberately unpleasant because that should act as a deterrent to future offending behaviour and crime. Manipulation, distrust, despair, bitterness and hostility are rife in most Cameroon prisons. The prison experience is often traumatic and threatens the psychological core or emotional balance of inmates. Krystal (1978:90) defines trauma as 'a paralysed, overwhelmed state with immobilisation, withdrawal, possible depersonalisation 
and evidence of disorganisation.' McCann and Pearlmann (1990:74) point out that trauma can have profound effects on a person's self-esteem. According to Laufer (1988:38), the exposure to a hostile environment fundamentally undermines the ability of a person to unfold his or her potential, which in turn shatters the self-system.

Development takes place in a social and cultural context as people absorb information from their environment. They develop certain expectations and beliefs about themselves, others and the world which form a framework for the interpretation of experiences. If learning and development were to take place, it would be necessary to enhance the selfcapacities of inmates in order to enable them to maintain a consistent sense of identity and positive self-esteem. Murphy and Dison (1990:141) advocate supportive therapy in a rational and reality-oriented manner in order to facilitate the learning of appropriate behaviours for handling day to day problems.

\section{Communal and individual pastoral care}

On a communal level pastoral caregivers can help to draw public attention to the many challenges that face the penitentiary system. They can promote a better understanding of the needs of prisoners amongst the family and friends of inmates, government officials and civil society. On a more personal level they can provide spiritual care to inmates themselves.

Faith communities could (and should) lead the way to provide pastoral care that is relevant to the context of prisoners in Cameroon. Such pastoral care would provide care in the crisis situations of hunger, thirst, sickness and disease and a lack of love and concern. Yu (1991:62-68) points out that the prison as a setting for pastoral care, and counselling is radically different from other pastoral settings such as the parish, a hospital or the military.

According to Griffith (1993:190-193), those in prison are part of the faith community. As was the case in the early church, faith communities today still have the responsibility to visit and care for people in prisons. Campbell and Halloway (1973:147-148) point out that the injunction to 'visit the prisoners' in the Bible has not been taken seriously enough by many faith communities. There are people who have been in prison for decades without having received a single visit. The biblical call to visit the prisoners is a call to be faithful to the gospel message of salvation in Jesus Christ. Griffith (1993:118) puts it as follows: 'In Matthew 25 we read that Jesus preached to individuals and to nations: care for prisoners, visit them, set them free.'

The faith community is called to be of service to those who have been victimised and violated by the machinations of the judicial process. According to Griffith (1993:191), the faith community is called to transform the old reality into something new by offering persistent love and nurture toward the healing of victims of injustice. This calls for increased personal and communal involvement, for the faith community to minister to victims of injustice with loving service and not with doctrinal demands or quick solutions to emotional crises. Faith communities can serve as places of refuge (Griffith 1993:203).

Mediation is another service that faith communities could render to prisoners and society. Bringing victims and offenders together in the presence of a third party who acts as mediator, could help to resolve issues, break the cycle of violence and bring about reconciliation. Faith communities can also mobilise the broader community to become involved in movements for justice, peace and service (Griffith 1993:204-225).

During the 2009 Africa Regional Conference for Prison Chaplains, which was organised by the International Commission for Catholic Prison Pastoral Care in Cape Town, South Africa, Ms Hlengiwe Mkhize (2009) called faith communities the moral authority of the most vulnerable. She put it as follows:

we expect the church and other faith based organisations to take a strong stand when deaths in correctional centres are reported and when offenders are deprived of other rights and privileges such as parole. (p. 1)

Pastoral care should go beyond rehabilitation and reintegration and situate itself at the very heart of correcting offending behaviour.

Leadership of the caregiving community and individual pastoral care are combined in Charles Gerkin's (1997: 17-18) approach to pastoral care which he calls a 'narrative, hermeneutical methodology for doing practical theology in pastoral care and counselling with individuals and in pastoral leadership of a community of Christian people.' According to him, the care of the people of God (community) involves the pastor caring for individuals with as much psychological insight as he or she can muster. Prisoners who are lost, abandoned and left to fend for themselves in the midst of harsh realities need attention, care and understanding from loved ones, the church and the community. Gerkin's (1997:21, 27-28) model of the pastor as shepherd (caring leader) who attends to the lost sheep in order to bring them home to the shepherd's loving embrace, is well suited for application to pastoral care with people in prison. The shepherd's role is comparable to that of Jesus Christ who seeks and saves the lost (Jn 10:10). The shepherding model sees the church as a community that offers help, counsel and nurtures its members to wholeness of life. Gerkin's shepherding model has a community approach to pastoral care to those who are vulnerable and marginalised in society.

With regard to the individual and personal dimension, pastoral care is about human interrelationships and touches on individual experiences and personal values (Campbell 1986:18). The concept of hope ties in with that of shepherding 
in that the aim of shepherding pastoral care is to guide individuals to transcend the hopelessness and helplessness of their situation. Prisoners often experience their environment as a life in darkness and they are searching for a ray of hope. The future seems bleak and uncertain. They do not know what the next day has in store. This is where pastors as agents of hope have a major role to play. However, it is difficult to be an agent of hope if all hope has been lost. In the prison environment probably the primary task of pastors is that of nurturing and fostering hope. The pastor as an 'agent of hope' (Capps 1995) searches with the individual for meaning in life and hope for the future. Through hope a transition can be negotiated (Capps 1995:25,51) in the lives of prison inmates. Through the ministry of hope the future can be experienced as 'open, unfrozen and full of opportunities' (Capps 1995:62-63) rather than as uncertain, threatening and hopeless.

An example of how important the capacity for hope is to prisoners, is illustrated by studies done with people who survived imprisonment in Nazi concentration camps during the Second World War. Physically the prisoners were captives of the Nazi regime but inwardly some of them were able to achieve a measure of freedom and hope. To project hope is to achieve some degree of autonomy in the present that can make a difference between life and death. By projecting a future hope the present is altered (Capps 1995:70).

Pastors as agents of hope have as their main aim to affirm the hope of the individuals in their care. Pastors also play the role of moralists who introduce moral feelings and judgements into pastoral counselling. This can help prisoners to redirect their inner suffering and cultivate an inner strength. Applying the model of Capps (1995:89, 117, 164) to the situation of pastoral care with prisoners - the task of the pastor as an agent of hope - would be to help inmates to reframe and transcend the problems and difficulties in their lives. Pastoral caregivers as shepherds and agents of hope mediate a relationship of faith: reawakening, renewing and restoring a spirit of hope and trust in a crushing and lifethreatening situation.

\section{Two case studies of good practice Individual and communal}

A case study of good pastoral practice that focuses on the unique individuality and the specific circumstances of each prisoner and where the outcome is a hope-filled perspective on the future is the Nova Scotia Coverdale Chaplaincy project (Shaw 1994) with women prisoners. Challenges women face in prison differ from those of men. Women become involved in offending behaviour for different reasons than men. Emotionally and physically they often respond to sentencing and incarceration differently to men (Maden, Swinton \& Gunn 1994; cf. Matthews \& Francis 1996:233).

This pioneering chaplaincy project offered pastoral and spiritual counselling and care to both women in prison and to those in halfway houses in the community. Emotions such as pain, hurt, fear, horror, sadness and isolation often turn into aggressive actions that could lead to tragic incidents. These emotions affect the psychology of individuals and if their relationships with family members, friends and the community are not cordial and strong, such emotions could result in disoriented individuals and more criminal behaviour (cf. Atabong 2007:76 specifically with regard to Cameroon). The Nova Scotia Coverdale Chaplaincy (Shaw 1994) project focused on psychology and offered individual counselling sessions on a weekly basis to women with a history of abuse. Chaplaincy services combined counselling support with intensive therapy that resulted in growth, in the self-worth and self-esteem of the women. The working relationship between the women and the chaplains focused on issues such as:

- reducing the power difference between the therapist and the client

- sharing experiences

- allowing the women to set their own agenda

- allowing the women to set the pace

- a commitment to confidentiality

- social change (Shaw 1994).

Ex-offenders were given the opportunity to continue to attend counselling sessions after having been released into the community.

In an evaluation of the programmes at correctional centres like P4W, Manitoba and Nova Scotia, it was found that the women who had completed the chaplaincy programmes exhibited greater self-confidence, a better understanding of their own situation and had more control over their own lives (see Kendall 1993; Mooney 1993; Pollack 1994; Shaw 1994). They were also appreciative of the opportunity to make their own decisions (Matthews \& Francis 1996:187-188). Hope, human dignity and a greater measure of self-worth were the outcomes of this approach of individual pastoral and psychological care.

A case study of good pastoral care practice with the focus on teamwork and a pastoral care network is that of the Cotton End Baptist Church Bedford England (2010). Pastoral care teams under the supervision of the clergy attend to the needs of people in prison. The network supplements the work of the clergy. Pastoral care is the responsibility of the whole church.

The Cotton End Baptist Church Bedford England (2010:1) recognises pastoral care as the hallmark of a great church. Their aim is to develop the highest quality pastoral care that would give meaning to the church's life, witness and mission. Pastoral care is seen as the provision of spiritual, emotional, physical and practical support irrespective of the decisions that have been taken by those who are being cared for. Pastoral care does not involve judgement but its primary role is one of support. If an individual acts in a manner with which they do not agree they do not stop caring for the person. 
The pastoral care network of the church extends to the church, the community and the workplace. Initially they sought to work out how to make pastoral care within the family work best. The goal of pastoral care within the Cotton End Baptist Church Bedford England is that no one is missed out and that everyone receives an appropriate level of care. No one should be left without a person to turn to in times of need. The pastoral care network is coordinated by the pastoral care ministry leader and includes a team of people who share in pastoral care. The idea is that everyone who is part of the church and wider church family is connected to the pastoral care network or a pastoral caregiver. The overall team is under the supervision of the minister who meets regularly with the pastoral care coordinators (Cotton End Baptist Church 2010:1). The system of Cotton End Baptist Church Bedford pastoral care (2010:2) involves the following:

- Where a person is a member of a house group the pastoral care will operate through the house group either by the leader(s) or by others who take on pastoral care duties within the group.

- Where a person is not a member of a house group, they will informally be linked to a house group as a first point of contact. This typically takes the form of recognising when a person is absent from church and taking responsibility for following up absence and informing the pastoral care coordinators of any needs or concerns.

The pastoral care network is only part of the work the faith community does in the prisons. Much informal care and help is also given outside of the network. All caring relationships serve to enrich relationships and to show Christ's love in different ways.

In Cameroon the time, energy and resources for full-time prison chaplaincy are often lacking. In such a context the Cotton End system of volunteer teams under the leadership and supervision of the clergy who visit and offer pastoral care to prisoners could work well to alleviate the scarcity of the necessary care in prisons. The workload of clergy will be greatly reduced if their main responsibility is to identify the work that should be done and to equip the teams of voluntary workers to become effective pastoral caregivers.

\section{Pastoral care in Cameroon prisons - A challenge}

According to Rick Osmer (2008:152), models of good practice offer practitioners help in imagining how to do things better or differently. Models of good practice can be retrieved from the past and applied to urgent current situations. Insights from pastoral care models of good practice can be fruitfully applied in Cameroon in order to care for the physical, emotional, psychological and spiritual needs of people in prisons who have often been abandoned to fend for themselves as they fight to survive amid harsh prison conditions.

The conditions of prisons in Cameroon are dire and reform is needed. The quality of life of prisoners will be greatly improved through a faster, more effective judicial system that enforces justice more speedily for the many people who are awaiting trial throughout the country. Cordial prisoner-staff relationships, well-trained staff and good management relations will also improve prison conditions and lives of inmates. A different philosophy on punishment and rehabilitation is necessary before such relationships can be fostered. Renovation of dilapidated prisons is needed in order to provide a safe and secure environment in which people can serve out their sentences in a humane manner.

Prisons in Cameroon should become productive and rehabilitative. The objective should be to transform prisoners through work, education and vocational programmes that would enable them to become self-reliant. Frye (1982; cf. Griffith 1993:171) argues that given proper guidance and opportunities to develop themselves, many prisoners are capable of being transformed to become people with a sense of purpose and direction in life. Prison officials should be motivated, protected and equipped for the often-dangerous work they do. All people, including prisoners, should receive care and be treated with dignity.

Pastoral care is a necessary and essential aspect of prison reform and the rehabilitation of prisoners. Pastoral care by faith communities in Cameroon could help to restore human dignity and bring life and love to people in prisons. Pastoral care could enable offenders to accept responsibility for their wrongs, bring about reconciliation between victims and offenders and guide prisoners to become useful citizens upon their return to the community. Pastoral care can help people to reconstruct their lives and return to society as healed and whole people (cf. Murphy \& Dison 1990:13). The role of faith communities and pastoral caregivers as shepherds and agents of hope would be to serve as caring leaders who seek out those who are sick, lonely and lost in the wilderness of the prison. Pattison $(2007: 117,145)$ describes the challenge facing the faith community as follows: 'The church should do good to people, learn from them and build them up and not make people who are already having a bad time feel worse.'

Faith communities in Cameroon can play a much greater role to improve the lives of people in prison, not only by providing in some basic material and spiritual needs but also by playing a greater role in the moral development and rehabilitation of prisoners in order that they can return to society and be good citizens. Networking and team work are essential for prison pastoral care. Hope for the future can be nurtured through cordial relationships with the community, family and volunteer groups.

Prison chaplaincy in Africa requires an indigenous Africanbased theology to effectively address the therapeutic needs of prisoners. Authentic pastoral care models that are relevant to the context are necessary. Pastoral care with prisoners in Cameroon is still in its budding stage.

\section{Acknowledgements Competing interests}

The authors declare that they have no financial or personal relationship(s) which may have inappropriately influenced them in writing this article. 


\section{Authors' contributions}

A.K.A. (University of Pretoria) did the research for his Masters dissertation and the article was written under the supervision of Y.D. (University of Pretoria).

\section{References}

Allard, P. \& Allard, J., 2010, 'Prison chaplaincy, restorative justice and just equipping', Journal of Social Justice 21, 330-338.

Amnesty International Report 2011, viewed 25 July 2011, from http://www.amnesty. org/en

Atabong, J., 2007, Opening new doors: Pastoral work in the prison, Wacha Business, Douala.

Boh, H., 2010, 'Pius Njawe: A hero and a martyr gone missing', viewed 02 June 2011 from http://www.afrikanet.info/menu/medien/datum/2010/08/04/tribute-topius-njawe-by-boh-herbert/?type $=988 \mathrm{lcHash}=f g 734 \mathrm{bf935}$

Boh, H. \& Ntemfac, O., 1991, Prison graduate: The story of Cameroon calling, Apcon, Calabar.

Brakel, S., 1988, 'Prison management, private enterprise style: The inmates' evaluation', Journal of Criminal and Civil Confinement 14, 175-244.

Broomley, D.B., 1991, 'Academic contributions to psychological counseling: A philosophy of science for the study of individual cases', Counseling Psychology Quarterly 3(3), 299-307. http://dx.doi.org/10.1080/09515079008254261

Camp, S.D., Klein-Safran, J., Kwan, O.K., Dagget, D.M. \& Joseph, V., 2006, 'An exploration into participation in a faith-based program', Criminology and Public Policy 5(3), 529-550. http://dx.doi.org/10.1111/j.1745-9133.2006.00387.x

Campbell, A.V., 1986, Rediscovering pastoral care, Darton, Longman \& Todd, London.

Campbell, W.D. \& Halloway, J.Y. (eds.), 1973, And the criminals with him (Lk 23:33): A first-person book about prisons, Paulist Press, New York, NY.

Capps, D., 1995, Agents of hope: A pastoral psychology, Fortress Press, Minneapolis, $\mathrm{MN}$.

Chan, J., 1994, 'The privatization of punishment: A review of key issues', in P. Moyle (ed.), Private prisons and police: Recent Australian trends, pp. 37-62, Pluto Press, Marrickville.

Cohen, L., Manion, L. \& Morrison, K., 2001, Research methods in education, 2nd edn., Routledge Falmer, London.

Cotton End Baptist Church Pastoral care, 2010, viewed 03 November 2010, from http://www.cottonendbaptistchurch.co.uk

Duncombe, D.C., 1992, 'The task of prison chaplaincy: An inmate's view', The Journal of Pastoral Care 46(2), 383-390.

Frye, N., 1982, The great code: The Bible and literature, Harcourt Brace Jovanovich, New York, NY.

Gendreau, P. \& Andrews, D.A., 1990, 'Tertiary prevention: What the meta-analyses of the offender treatment literature tell us about 'what works", Canadian Journal of Criminology 32, 173-184.

Gerkin, C.V., 1997, An introduction to pastoral care, Abingdon, Nashville, TN.

Good News Bible with the Deuterocanonical books [1979] 1994, United Bible Societies, Nairobi.

Griffith, L., 1993, The fall of the prison: Biblical perspectives on prison abolition, Wm B Eerdmans Publishing Company, Grand Rapids, MI.

Hall, S.T., 2003, 'Faith-based cognitive programs in corrections', Journal of Corrections Today 65(7), 108-137.

Hall, S.T., 2004, 'A working theology of prison ministry', Journal of Pastoral Care 58(3), n.p.

Harding, R., 1992, 'Private prisons in Australia', Trends and Issues in Crime and Criminal Justice 36, 1-8.

Hatry, H., Brownstein, P. \& Levinson, R., 1993, 'Comparison of privately and publicly operated corrections facilities in Kentucky and Massachusetts', in G.W. Bowman S. Hakim \& P. Seidenstat (eds.), Privatizing correctional institutions, pp. 193-212, Transaction Publishers, New Brunswick.

Hutto, T.D., 1990, 'The privatization of prisons', in J.W. Murphy \& J.E. Dison (eds.), Are prisons any better? Twenty years of correctional reform, pp. 111-128, Sage, Newbury Park, CA \& London. (Sage Criminal Justice System Annuals).

James, A.L., Bottomley, A.K., Liebling, A. \& Clare, E., 1997, Privatizing prisons: Rhetoric and reality, Sage, London.

Jones, J.R., 2002, A grammar of Christian faith: Systematic explorations in Christian life and doctrine, Rowman \& Littlefield Publishers, Lanham, MD.

Kendal, K., 1993, Programme evaluation of therapeutic services at the prison for women, Correctional Service Canada, Ottawa.

Krystal, H., 1978, 'Trauma and effects', Psychoanalytic Study of the Child 33, 81-117.

Laufer, R.S., 1988, The real self: War trauma, identity, and adult development, in J.P. Wilson, Z. Harel \& B. Kahana (eds.), Human adaptation to extreme stress: From holocaust to Vietnam, pp. 33-51, Plenum Press, New York, NY.

Logan, C.H., 1987, Privatizing prisons: The moral case, Adam Smith Institute, London.
Logan, C.H., 1990, Private prisons: Cons and pros, Oxford University Press, New York, NY.

Logan, C.H., 1992, 'Well kept: Comparing quality of confinement in private and public prison', Journal of Criminal Law and Criminology 83, 577-613. http://dx.doi. org/10.2307/1143839

Maden, A., Swinton, M. \& Gunn, J., 1994, 'A criminological and psychiatric survey of women serving a prison sentence', British Journal of Criminology 34(2), 172-191.

Matthews, R. \& Francis, P. (eds.), 1996, Prisons 2000: An international perspective on the current state and future of imprisonment, Macmillan, London.

Mbembe, A., 2001, On the postcolony, University of California Press, Berkeley, CA.

McCann, I.L. \& Pearlmann, L.A., 1990, Psychological trauma and the adult survivor: Theory, therapy and transformation, Brunner/Mazel, New York, NY.

McDonald, D., 1994, 'Public imprisonment by private means: The re-emergence of private prisons and jails in the United States, the United Kingdom and Australia', British Journal of Criminology 34 (Special issue), 29-48.

Mkhize, H., 2009, 'International Commission of Catholic Prison Pastoral Care', viewed 31 July 2011, from http://www.info.gov.za/speech/DynamicAction?pageid=461\& sid $=5019 \& \mid t i d=5164$

Mooney, G., 1993, 'Abuse hurts: A programme for incarcerated adult women survivors of family violence', paper presented at the 4th North American Conference on the Family and Corrections, Quebec, 12-15 October.

Mukong, A., 1990, Prisoner without a crime, Calvert, London.

Murphy, J.W. \& Dison, J.E. (eds.), 1990, Are prisons any better?: Twenty years of correctional reform, Sage, Newbury Park, CA.

National Commission on Human Rights and Freedoms (NCHRF), 2007-2008, 'Report of the state of human rights in Cameroon 2007-2008', viewed 21 December 2011, from http://www.cndhl.cm, fr.allafrica.com/stories/200802060763.htm

Njawe, P., 2006, 'Don't lock up information: Stop jailing journalists', in World Association of Newspapers, viewed 31 July 2010, from http://www.dibussi. com/2006/05/pius_njawe_in_h.htm

O'Connor, T.P. \& Duncan, J.B., 2008, 'Religion and prison programming: The role, impact and future direction of faith in correctional systems', Offender Programs Report 11(6), 81-96.

O'Neill, K.L., 2009, 'The reckless will: Prison chaplaincy and the problem of Mara Salvatrucha', Public Culture 22(1), 67-88. http://dx.doi.org/10.1215/089923632009-016

Oppler, S., 1998, Correcting corrections: Prospects for South Africa's prisons, Institute for Security Studies, Halfway House.

Osmer, R.R., 2008, Practical theology: An introduction, William B. Eerdmans Publishing Company, Grand Rapids, MI/Cambridge, UK.

Pattison, S., 2007, The challenge of practical theology: Selected Essays, Jessica Kingsley Publishers, London/Philadelphia, PA.

Pollack, S., 1994, 'Opening the window on a very dark day: A programme evaluation of peer support team at the Kingston prison for women', MA thesis, Psychology Department, Carlton University School of Social Work.

Prisons in Cameroon, 2002, 'Report of the Special Rapporteur on prisons and conditions of detention in Africa: The African Commission on Human and Peoples' Rights (ACHPR/37/OS/11/437)', viewed 31 January 2010, from http://www.achpr. org/english/Mission_reports/Special\%20Rap_Prison_Cameroon.pdf

Rule, P. \& John, V., 2011, Your guide to case study research, Van Schaik Publishers, Pretoria.

Ryan, M. \& Ward, T., 1989, Privatization and the penal system: The American experience and the debate in Britian, Open University Press, Milton Keynes.

Selke, W.L., 1993, Prisons in crisis, Indiana University Press, Bloomington, IN.

Shaw, M., 1994, 'Women in prison: A literature review; forum on corrections research', Forum on Corrections Research 6(1), 22-25.

Schichor, D., 1995, Punishment for profit: Private prisons/public concerns, Sage, London.

Silverman, D., 2000, Doing qualitative research: A practical handbook, Sage, New Delhi.

Skotnicki, A., 2000, Religion and the development of the American penal system, University Press of America, Landham, MD.

Stern, V., 1998, A sin against the future: Imprisonment in the world, Penguin Books, London.

Ungar, M., 2003, 'Prisons and politics in contemporary Latin America', Human Rights Quarterly 25, 909-934. http://dx.doi.org/10.1353/hrq.2003.0053

VandeCreek, L., Bender, H. \& Jordan, M.R., 2008, Research in pastoral care and counseling: Quantitative \& qualitative approaches, Wipf \& Stock, Eugene, OR.

Wakai, N., 2000, Inside the fence: Reminiscences as a detainee, Patron Publishing, Bamenda.

Ward, T. \& Maruna, S., 2008, Rehabilitation: Beyond the risk paradigm, Routledge, London/New York, NY.

Williamson, C.M., 1999, Way of being, way of life: A Christian theology, Chalice Press, St. Louis, MO.

Yin, R.K., 1994, Case study research: Design and methods, 2nd edn., Sage, Newbury Park, CA.

Yin, R.K., 2003, Applications of case study research, 2nd edn., Sage, Thousand Oaks, CA.

Yu, G., 1991, 'Prison pastoral care: The Seer as a new paradigm', Pastoral Psychology 40(1), 59-69. http://dx.doi.org/10.1007/BF01027535 